\title{
TOURISM TERRITORIAL BRANDING IN THE CONDITIONS OF THE COVID-19 PANDEMIC (ON THE EXAMPLE OF UKRAINE AND POLAND)
}

\author{
Oleh Karyy', Uliana Balyk², Nataliia Kara ${ }^{3}$
}

\begin{abstract}
In conditions of the deep crisis caused by the COVID-19 pandemic, there is an urgent need to find effective ways to reboot the tourism industry. Territorial branding as a tourism marketing tool is one of such ways. Therefore, the purpose of this article is to compare the features of tourism branding in Ukraine and Poland, taking into account the impact of the COVID-19 pandemic on the tourism industry and consumer behavior. The study is grounded on the use of general and specific methods based on a systematic approach to the study of tourism branding opportunities in Ukraine and Poland before and during the COVID-19 pandemic: analysis and synthesis - used to compare the competitiveness of tourism, brand, development status and trends in the tourism industry of countries; deduction and induction - used to describe the impact of the COVID-19 pandemic on tourism development and outline the problems of competitiveness of countries' tourism; abstraction and generalization - used to provide recommendations on how to improve countries' tourism branding. The article revealed that tourism plays a significant role in the economy of Ukraine and Poland and is closely linked with other industries. A comparison of the weaknesses and strengths of the countries' tourism competitiveness made it possible to identify basic components that need to be improved. It was found that Ukraine and Poland are in constant search of optimal tourist brands. The authors investigated the specifics and retrospective development of tourist brands by government bodies in both countries. The concept of the latest versions of the tourist brand is to show Ukraine as an open, modern country where all the most interesting things are happening right now (Ukraine NOW), and Poland as a country that can expand the imagination of visitors (Poland. Move your imagination). Based on a comparison of various international rankings levels of tourist brands of these countries, it was found that Poland has a much better performance than Ukraine. In addition, the authors thoroughly investigated the effects of the COVID-19 pandemic on tourism development in both countries and changes in tourism consumer behavior. The article offers recommendations for improving the tourism brands of countries, taking into account the new epidemiological conditions.
\end{abstract}

Key words: tourism brand, competitiveness, COVID-19 pandemic, consumer behavior.

JEL Classification: M31, E20, O57

\section{Introduction}

Tourism is an important segment of the global economy and a key element in the preservation of natural and cultural heritage because one in 10 people on Earth is employed in the tourism industry, and it provides a livelihood for hundreds of millions of people (The United Nations, 2020; Prokopenko and \& Omelyanenko, 2020). Moreover, tourism as a system has proven quite resilient to various external shocks (e.g., the September 11 terrorist attacks (2001), the Severe Acute Respiratory Syndrome (SARS) outbreak (2003), the global economic crisis (2008/2009), the Middle East Respiratory Syndrome (MERS) of 2015). Yet, the COVID-19 pandemic has created radically different conditions for the survival of the tourism industry. The situation is aggravated by the fact that

\footnotetext{
Corresponding author:

${ }^{1}$ Lviv Polytechnic National University, Ukraine.

E-mail: oleh.i.karyi@lpnu.ua

ORCID: https://orcid.org/0000-0002-1305-3043

${ }^{2}$ Lviv Polytechnic National University, Ukraine.

E-mail: uliana.o.balyk@lpnu.ua

ORCID: https://orcid.org/0000-0001-8379-4907

${ }^{3}$ Lviv Polytechnic National University, Ukraine.

E-mail: nataliia.i.kara@lpnu.ua

ORCID: https://orcid.org/0000-0001-7000-2931
} 
traveling and tourism simultaneously contribute to the spread of the disease and its economic consequences, so some experts even compare it with the current climate crisis. It is worth emphasizing that, unlike other business segments, income from tourism is lost forever because unsold capacity cannot be sold in the following years, with corresponding consequences for employment in the segment (Gössling et al., 2021).

In 2020, tourism faced the deepest crisis with the international arrivals drop by $74 \%$ due to widespread travel restrictions and a substantial decline in demand. The World Tourism Organization (2021) predicts the tourist activity recovery for the second half of 2021: July 66\% growth compared to 2020 and $55 \%$ decline compared to 2019 ( 1 scenario); September 22\% (2020), -67\% (2019). Nevertheless, JanuaryFebruary 2021 faced a decline in international arrivals: $-87 \%$ (2020). Overall, tourism can recover in 2.54 years or even longer, depending on the pandemic development.

Meanwhile, it is interesting that health-related crises have historically caused "unscientific" and disproportionate global responses that have mostly affected the tourism industry (Novelli et al., 2018). It is confirmed by the research of the World Bank (2020), which specifies that society tries to avoid infection and makes non-coordinated and irrational efforts leading to $90 \%$ of all economic losses related to epidemics and outbreaks.

It is worth mentioning that domestic tourism recovers quicker in crisis due to its scales and it is called the driver of tourism industry recovery. In particular, in the European Union the expenditure on domestic tourism exceeds the costs of inbound tourism by 1.8 times (World Tourism Organization, 2021).

Tourist behavior is transformed by the consequences of the pandemic, such as the revision of a person's psychological distance and his perception of new risks (Wen et al., 2021). Marketing can be an effective measure to influence tourist behavior during and after the COVID-19 pandemic and manage the subjective aspects of perceived risk (Matiza, 2020; Tkach, 2013). Namely, territorial branding is an efficient marketing tool in the tourism industry.

\section{Literature review}

The brand has now become a traditional characteristic of countries. Nevertheless, the first theoretical studies of territorial marketing (place marketing) and branding are relatively recent (1990s). Kotler P., Haider D.H. and Rein I. (1993) the concept of strategic place marketing, according to which places and territories should operate as businesses and sell themselves as businesses if they respond adequately to global threats, competition and technological change. Meanwhile, the concept of place branding was suggested by Anholt, S. (2010), who argued that the theory of brands has finally reached the governments of cities and countries through commercial practices and reached it mainly in two ways: tourism and export marketing. The country or region is responsible for the overall image of the site, leaving private operators to market specific services to end users. Yet, the government's main task is to combine them in the consciousness of an end-user. Therefore, the government creates an umbrella brand for private providers of tourism services, destinations, attractions in public and private ownership.

Nowadays, we understand the brand of a territory as a network of associations in the consciousness of site consumers that is grounded on the visual, verbal, and behavioral expression of the site and its stakeholders (Zenker and Braun, 2017). Associations vary in their impact on the network and their role in the attitudes and behavior of site consumers. Anholt S. (2010s) suggests combining six forces that generate the perception of any country: tourism and desire to visit a country, people, culture and heritage, investment and migration, foreign and domestic policy, and export - goods and services.

There are two approaches to the vector of country brand orientation: an externally oriented phenomenon (i.e. a carrier/conductor to an external country of ideas, which a particular country is) (P. van Ham, 2001); 2) a country brand is both an internally and externally oriented phenomenon, which is spread through slogans, logos and information campaigns. The perception (and acceptance) and ongoing re-translation by residents of all segments of the population is another important component of the process (Aronczyk, 2008).

Overall, the process of territorial marketing includes two main stages: positioning and promotion. When positioning, the strongest and most exceptional characteristics of the territory are determined, which will be used to form its unique position in the future. Meanwhile, the promotion with the help of various means of communication helps to skillfully make a statement to the selected target audience, taking into account marketing goals (Decentralization, 2021).

However, one should not hope that the tourism brand of the country can be formed only through marketing, because a strong brand needs such basic elements as a developed infrastructure, economic sustainability, effective public administration, developed civil society, etc. Nevertheless, the role of marketing should not be underestimated, as targeted marketing campaigns have repeatedly played a crucial role in reducing the risks associated with travel and tourism perceived by visitors (Matiza, 2020).

Practice shows that territories that gradually implement interrelated marketing activities, including branding, achieve sustainable development goals 
much faster than territories that do not (Gössling et al., 2021; Novelli et al., 2018; Matiza, 2020).

Among other things, in a pandemic, the tourism branding of a territory requires a quick adjustment. Wen J., Kozak M., Yang S., Liu F. (2021) studied the main effects of COVID-19 on tourist behavior patterns and hypothesized that health emergencies generate three types of tourism: from general to complex, from open to closed, and from radical to conservative. Seminary marketing theory states that consumer behavior responds more to the subjective impact of perceived risk than to an objective assessment of risk (Bauer, 1967). Personal and physical safety issues have a significant impact on tourist decisions and choices (Novelli et al., 2018; Bondarenko and Romaniuk, 2021). Namely, World Tourism Organization (2021) emphasizes the following key changes in travelers' behavior in the pandemic: they prefer domestic tourism, in particular, travelers going for "staycations" or vacations close to home; health and safety measures and cancellation policies have become the main concerns of consumers; last-minute bookings; nature, rural tourism, and road trips have become popular travel options; young people are more likely to reclaim travel than older generations; travelers place greater importance on creating a positive impact on local communities, increasingly seeking authenticity.

Ukraine and Poland, as neighboring countries of Central and Eastern Europe, have similar geopolitical, natural, demographic, socioeconomic, and cultural conditions. However, under market conditions, the competition of countries for tourists turns them from geographical units into goods, which have their own value, properties and value. The change in the paradigm of consumer behavior of tourist services leads to an additional need for a comprehensive study of the development of the tourism industry in Ukraine and Poland before and during the COVID-19 pandemic.

\section{Aims and methods}

The aim of the article consists in comparing the features of tourism branding of Ukraine and Poland considering the impact of the COVID-19 pandemic on the tourism industry and its consumer behavior. On the basis of this goal, the study has the following objectives:

- to perform a comparative analysis of the place that the tourism industry takes in the economy of countries, and their tourism competitiveness among countries of the world;

- to explore how public authorities are developing tourism brands of countries;

- to carry out a comparative analysis of the level of the countries' tourism brands on an international scale;
- to evaluate the consequences of the COVID-19 pandemic on countries' tourism development and consumer behavior;

- to develop recommendations for improving the tourism brands of countries in the context of recovered tourism.

In the article the authors use the method of literature review to substantiate the importance of territorial branding in tourism at the national level and, therefore - to justify the relevance of the chosen topic of research. The study is founded on general and specific methods based on a systematic approach to the study of tourism branding opportunities in Ukraine and Poland before and during the COVID-19 pandemic: analysis and synthesis comparison of tourism competitiveness, brand, state of development and trends in the tourism industry of countries; deduction and induction - description of the impact of the COVID-19 pandemic on tourism development and identification of tourism competitiveness problems of countries; abstraction and generalization - to provide recommendations on how to improve the tourist branding of countries.

\section{Discussion and research results}

\section{The place of the tourism industry in the countries' economies}

Ukraine and Poland have significant tourism potential with unique cultural, historical, natural and geographical, socio-demographic and economic components. According to the World Travel \& Tourism Council, in Ukraine the share of travel and tourism industry in the GDP is higher than in Poland (5.9\% against $4.7 \%)$, same as its annual growth (6.1\% against $4.0 \%)$. Travel and tourism industry has provided 1028800 jobs or $6.2 \%$ of total employment in Ukraine. Meanwhile, in Poland there are 811,800 jobs, or $5.0 \%$ of total employment. Nevertheless, it is worth noting that the data is taken from official statistics, and given the high level of shadow activity in the tourism industry in both countries, the figures are actually much higher. In terms of the share of international visitors in total exports, the travel and tourism industry is dominated by Poland $-4.4 \%$ or $\$ 14,300,000$. While in Ukraine, the rates were $3.3 \%$, or $\$ 2,251,800,000$. The share of domestic expenses in Ukraine is 2.3 times higher than in Poland (70\% against 31\%), and the share of international expenses is 30\% against 69\% in Poland. In both countries, spending on leisure prevails over spending on business: $91 \%$ against $9 \%$ in Ukraine and $66 \%$ against $34 \%$ in Poland.

\section{The countries' tourism competitiveness}

According to the World Economic Forum's The Travel \& Tourism Competitiveness Index 2019 (World Economic Forum, 2019), Ukraine's points increase 
in the rankings was the largest in the sub-region. It moved up 10 positions to $78^{\text {th }}$ in the world. Namely, when Ukraine stabilized and recovered economically, it abruptly improved its business environment, security, international openness and general infrastructure. In the meantime, Poland is the largest scientific-technological economy in the region and second by competitiveness. The country benefits from higher scores for natural and cultural resources, with the latter category having the best scores in the Balkans and Eastern Europe.

A more detailed comparison of the competitiveness of tourism in both countries (Table 1) shows that they have similar indicators in the category Human Resources and Labor Market. There are slight differences on 1-3 points in areas such as Business Environment, Health and Hygiene, Travel and Tourism Priority, Price Competitiveness, Environmental Sustainability, Tourism Services Infrastructure. It is worth noting that the effectiveness of marketing and brand in attracting tourists is one of the key indicators for determining the level of priority of travel and tourism in countries. Obviously, both countries rank relatively low in terms of Prioritization of Travel \& Tourism $\left(92^{\text {nd }}\right.$ and $\left.98^{\text {th }}\right)$. Meanwhile, the following competitive advantages are much stronger in Poland: Cultural Resources and Business Travel, Ground and Port Infrastructure, Natural Resources, ICT Readiness, Safety and Security. Competitive advantages such as price competitiveness and health and hygiene are slightly stronger in Ukraine than in Poland.

Overall, the weaknesses in tourism competitiveness for both countries compared to others were as follows: Business Environment, Travel and Tourism Prioritization, and Environmental Sustainability. This indicates a lack of prioritization and importance of the tourism industry among other segments of the economy, poor conditions of tourism business, a high level of shadow activities in the industry, low level of culture in terms of compliance with the principles of sustainable tourism among the industry stakeholders, as well as among the local population and tourists.

\section{The countries' tourism brands}

Understanding the instability of the international tourism market, Ukraine and Poland are in constant search for optimal tourist brands. Ukraine made its first attempt to improve its national image in 2005, but for organizational reasons it failed to create a brand. In 2007 the State Service of Tourism and Resorts under the Ministry of Culture presented a tourist brand "Snowy Winter" with the slogan "Ukraine for the snow lovers" (Letunovska, and Lyulyov, 2020). The question of new branding for the country was resurfaced before the 2012 European Football Championship. In 2011 the Strategy of Ukraine's Positioning Abroad was presented. Its main slogan was "Ukraine Openness", which was supposed to show Ukraine's openness to reforms, tourism development, readiness to participate in global processes and investments. In 2014, a new Ukrainian brand was presented with the slogan "Ukraine. All about U" and cultivating such values as trust, dignity, responsibility and geodiplomacy related to Ukraine's ability to live "in between" (Ukraine tourist brandbook, 2014). The complex of activities under this concept took place

Table 1

T\&T Competitiveness Index 2019 Overall Rankings

\begin{tabular}{|l|c|c|}
\hline & Ukraine & Poland \\
\hline T\&T Competitiveness Index 2019 Overall Rankings & $78(3.7)$ & $42(4.2)$ \\
\hline Subindex A: Enabling Environment & $65(5.0)$ & $55(4.5)$ \\
\hline Subindex B: T\&T Policy and Enabling Conditions & $70(4.5)$ & $50(4.0)$ \\
\hline Subindex C: Infrastructure & $73(3.4)$ & $34(3.1)$ \\
\hline Subindex D: Natural and Cultural Resources & $89(2.1)$ & $91(4.3)$ \\
\hline Pillar 1: Business Environment & $103(4.1)$ & $56(5.6)$ \\
\hline Pillar 2 Safety and Security & $107(4.8)$ & $24(6.3)$ \\
\hline Pillar 3: Health and Hygiene & $11(6.5)$ & $53(4.8)$ \\
\hline Pillar 4: Human Resources and Labour Market & $48(4.8)$ & $39(5.5)$ \\
\hline Pillar 5: ICT Readiness & $78(4.5)$ & $98(4.2)$ \\
\hline Pillar 6: Prioritization of Travel \& Tourism & $92(4.3)$ & $33(4.1)$ \\
\hline Pillar 7: International Openness & $55(3.7)$ & $40(5.7)$ \\
\hline Pillar 8: Price Competitiveness & $19(5.9)$ & $81(4.2)$ \\
\hline Pillar 9: Environmental Sustainability & $114(3.9)$ & $56(3.2)$ \\
\hline Pillar 10: Air Transport Infrastructure & $71(2.7)$ & $37(4.3)$ \\
\hline Pillar 11: Ground and Port Infrastructure & $77(3.1)$ & $56(4.5)$ \\
\hline Pillar 12: Tourist Service Infrastructure & $65(4.3)$ & $55(3.2)$ \\
\hline Pillar 13: Natural Resources & $116(2.2)$ & $28(3.0)$ \\
\hline Pillar 14: Cultural Resources and Business Travel & $55(1.9)$ & \\
\hline
\end{tabular}

Source: World Economic Forum, 2019 
in several stages: 1) information of the projects was aimed at general presentation of Ukraine to the world - "Switch on Ukraine" (tourist opportunities, investment attractiveness, etc.); 2) programs and activities were more specific (ethnical tourism, investments in specific industries and national projects, etc.), which was expressed in the slogan "Ukraine. Moving along the fast lane".

The concept of the latest tourism brand (accepted on May 10, 2018) is to demonstrate Ukraine as an open modern country, where all the most interesting things are happening right now. A survey of perceptions of Ukraine abroad conducted with the support of the British government (State Agency for Tourism Development of Ukraine, 2021) shows that corruption, revolution and military actions are the three most popular associations with Ukraine. The image is formed mainly by what people see and hear in the news. However, those who have been in Ukraine think differently and emphasize the hospitality of Ukrainians, beautiful landscapes, culture and architecture. The new campaign and branding idea is based on the word "NOW" because research shows that this moment of change is important for modern people from all over the world, tourists and investors. Thus, the logo (Figure 1a) as if "highlighted" in yellow the main word in the application - NOW, and the blue element resembles the form of a notice in social networks. It is a symbol of something new, something that catches the eye (State Agency for Tourism Development of Ukraine, 2021).

In 2019, the State Agency for Tourism Development of Ukraine launched the "Ukraine's Magnets" program to attract investment. The first projects were: Chornobyl: Renaissance, Danube Riviera, Khortytsia Island, Pylypets, and Promprylad. Renovation (State Agency for Tourism Development of Ukraine, 2021). In 2020 a large-scale national project "Travel Ukraine" was launched, aimed at promoting travel destinations, which is very timely in terms of the pandemic. Ukraine.ua was officially launched in 2021. It has become a major resource for tourists and business investors.

Poland is one of the countries that have been successful in promoting the national tourist product. In particular, the country is constantly holding active marketing campaigns both internationally and domestically. In 2009 a tourist brand with the slogan "Polska. Move your imagination" was developed. The brand logo (Figure 1b) is a collage with visual themes and icons related to Poland and its culture, to demonstrate the diversity and appeal of Polish heritage from different perspectives, both in contemporary style and in old folklore traditions. (The Polish Tourism Organisation, 2021). In addition, in 2008-2015 was implemented a project of tourist marketing "Promujmy Polskę Razem". Its purpose is to support and intensify activities to promote Poland in cooperation with all organizations involved in the positioning of the country in the world, to increase the effectiveness of marketing activities to promote Polish tourism, increase the number of international tourists and their spending in Poland, as well as to extend the tourist season in the country (Nikolaichuk, 2020).

In 2012, the "I Like Poland" project was launched, aimed at increasing Poland's competitiveness in Asian markets - namely China, India and Japan. The project implementation was meant to increase the revenues and expenditures of international tourists from these countries. In addition, as part of cooperation with the EU in 2010-2012, the project "Eastern Poland Promotion" was implemented. It was aimed at increasing interest in the tourism offer of the five voivodeships of Eastern Poland, focusing on domestic (including residents of Eastern Poland) and international tourists (Germany, Ukraine). With the help of the Polish government a number of successful programs to promote domestic tourism (in particular, "Poland See More - Weekend at half price") have been

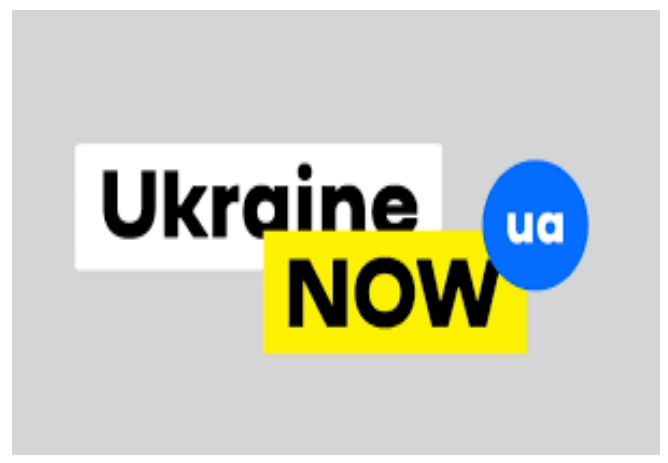

a) Ukraine

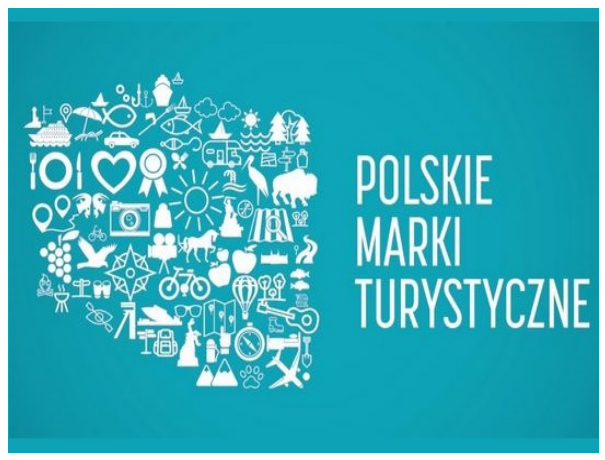

b) Poland

Figure 1. Brand's logo

Source: State Agency for Tourism Development of Ukraine; The Polish Tourism Organisation 
put forward. The Ministry of Sports and Tourism, in cooperation with the Polish Tourist Organization, implemented the project "Polish Tourist Stamps" (until September 16, 2019) (The Polish Tourism Organisation, 2021). Its main goal was to improve the branding of regions by developing tour packages, combined into one and promoted as a tourist brand.

Creating mobile electronic applications for smartphones and tablets is a valuable e-marketing tool to promote a travel brand in the context of rapid digitalization. There are much more such applications in Poland (Turystyka w Polsce, Poland. Travel, Poland Travel Guide Offline, Thetripplanner, Ski Raport, Castles of Poland, Poland Tourist Map Offline, Guide With Me, Noclegi, hotele, pokoje w Polsce, Poland A GuidetoMajorCities) than in Ukraine (Ukraine Inside Out, Ukraine Travel \& Explore, Offline Tourist Guide, Turyst Ukrayiny) (Google Play App, 2021).

In general, such central executive authorities as the Ministry of Culture and Information Policy and State Agency for Tourism Development of Ukraine are responsible for the tourism attractiveness in Ukraine and tourism development vector in the country. In Poland, these are the Ministry of Economic Development and Technology and the Polish Tourism Organization with 14 international offices.

Meanwhile, destination branding in Eastern and Central Europe is accompanied by the following problems: lack of proper funding to support appropriate marketing campaigns; pressure on tourism branding experts to ensure short-term results; difficulties in developing a single brand for a destination consisting of a large number of products and environments (Nikolaichuk, 2020).

Evaluating the tourist brands of Ukraine and Poland at the international level, it is worth paying attention to the study of the official data partner of the World Economic Forum - Bloom Consulting. Every two years it publishes the Country Tourism Brand Ranking by the following criteria: 1) economic indicators (key parameters: the average rate of total annual receipts of international tourists to the country and the average growth of total annual receipts of international tourists to the country); 2) digital demand (total volume of online searches for tourism-related activities and attractions in all countries included in the ranking); 3) CBS ranking (comparing the most popular brand tags for a particular country with the most actively promoted brand tags of national tourism organizations in that country), as well as online indicators (number of total visits to the official web page and average time spent per visitor, number of likes and followers on social networks) (Bloom Consulting, 2021). According to 2019-2020 data, Ukraine ranks $98^{\text {th }}$ in the world and $34^{\text {th }}$ among European countries, while Poland ranks $39^{\text {th }}$ and $18^{\text {th }}$, respectively. In particular, the level of the country brand strategy in Poland is estimated by experts as a level (Slightly Strong), and in Ukraine it is a level lower BBB (Very Good). Moreover, the position of Ukraine decreased by 2 points, and Poland remained in the same position.

The Future Brand Country Index evaluates brands on the following parameters: Values System, Quality of Life, Business Potential, Heritage \& Culture, Tourism, and Products \& Services. Also, additional topics are considered within each parameter like natural beauty, food, tolerance, and political freedom (Future brand, 2021). Moreover, the brand strength is quantified by comparing their "online talk-ability". Data for 2019 show that Poland and Ukraine ranked penultimate and last among European countries, $44^{\text {th }}$ and $74^{\text {th }}$ in the world, respectively. Meanwhile, the World Bank ranking positions Poland as $23^{\text {rd }}$ and Ukraine as $60^{\text {th }}$.

Peculiarities of tourism industry development in countries before the COVID-19 epidemic

Speaking about the tourism branding of Ukraine and Poland, it is necessary to consider the peculiarities of the tourist industry before and during the pandemic. Thus, in 2019, there were more than 4,600 travel companies in Ukraine, and more than 11,000 travel companies in Poland. Comparison of Ukraine and Poland on the main parameters of collective accommodation facilities in 2019 shows the advantage of the latter (Table 2). Namely, the number of collective accommodation facilities and their capacity in Poland is twice higher than in Ukraine. The main difference is that in Ukraine hotels and similar accommodation facilities account for $59.3 \%$ of the total number of collective means of accommodation, while in Poland, the rate is $37.6 \%$, which shows a more developed tourism infrastructure. Meanwhile, the share of hotels and similar lodging facilities in total accommodation capacity is about the same in Ukraine and Poland (46.3\% and 44.7\%, respectively). In Poland in 2019, the number of people staying in collective accommodation facilities and the number of nights spent there is more than 5 times higher than in Ukraine. While in Poland overnight stays of international tourists in such facilities account for $20 \%$ of the total number, in Ukraine - $10.9 \%$.

It is worth noting that by 2014 Ukraine has surpassed Poland in terms of inbound tourism. Thus, in 2013, their number was about 25,000,000. visitors per year, while Poland failed to reach this level in 2010-2019. However, in 2014, the Russian Federation annexed part of Ukrainian territory (the Crimean Autonomous Republic) and is still engaged in military operations in Donetsk and Luhansk regions. This had a significant impact on the tourist attractiveness of the country. Poland, meanwhile, 
Table 2

Main parameters of collective accommodation facilities' activity in Ukraine and Poland in 2019

\begin{tabular}{|l|c|c|}
\hline \multicolumn{1}{|c|}{ Parameters } & Ukraine & Poland \\
\hline Number of collective accommodation facilities & 5335 & 4251 \\
\hline including hotels and similar accommodation facilities & 3165 & 825522 \\
\hline Beds & 370560 & 368944 \\
\hline including hotels and similar accommodation facilities & 171721 & 35668100 \\
\hline Number of persons staying in collective accommodation facilities & 6960949 & 7470500 \\
\hline including international tourists & 959423 & 93342700 \\
\hline Number of overnight stays (over one night) & 18459138 & 18683600 \\
\hline including international tourists & 2016623 & \\
\hline
\end{tabular}

Source: Statistic Poland; The State Statistics Service of Ukraine

has seen a steady annual increase in inbound tourists. As of 2019, the number of inbound tourists coming to Ukraine was about $13,000,000$ and to Poland about 22,000,000.

It is worth pointing out that Euro 2012, held in Ukraine and Poland, was a powerful driver of tourism development and contributed to the recognition of their tourism brands. Preparations for this event greatly accelerated the creation of new accommodation facilities and the further development of tourist infrastructure in both countries (Figure 2). Nevertheless, the number of collective accommodation facilities decreased by more than $70 \%$ in Ukraine in 2014 due to the military aggression of the Russian Federation and continued to fall until 2018. Figure 2 shows that while in 2011 the gap between Poland and Ukraine on the number of collective accommodation facilities was only $22.5 \%$, after 9 years it was $110.9 \%$. So it is a good example of how territorial branding for some events can be used to further the development of domestic tourism.

Consequences of the COVID-19 pandemic for tourism and consumer behavior in the countries

The COVID-19 pandemic has significantly affected tourism in Ukraine and Poland. Like other countries around the world, these two European countries have had to resort to avoidable travel restrictions, both domestically and internationally. The severity of restrictions varied depending on the epidemiological situation (Table 3), but they continued to affect the recovery of tourism.

In 2020, the number of foreigners entering the territory of Ukraine decreased by 4 times compared to the previous year. The volume of traffic in the airports of Ukraine in 2020 fell in 2.8 times, while the volume of regular flights - in 3.5 times, and charter - less than two times. Three times fewer passengers used railway transport (State Agency for Tourism Development of Ukraine, 2021). Analysis of the dynamics of the services provided shows that in contrast to their consistent growth in the range of $13-19 \%$ in 2019, in the following year they fell by $23.2 \%$ in the I quarter, $73.4 \%$ - in the II quarter, $45.5 \%$ - in the III quarter, and $41.2 \%$ in the IV quarter (The State Statistics Service of Ukraine, 2021). The situation in Poland is similar. In particular, the stay of tourists in accommodations decreased quite significantly in the first year of the pandemic: $17.3 \%$ in the I quarter, $80.9 \%$ - in the II quarter, $30.8 \%$ in the III quarter, and $69.2 \%$ in the IV quarter.

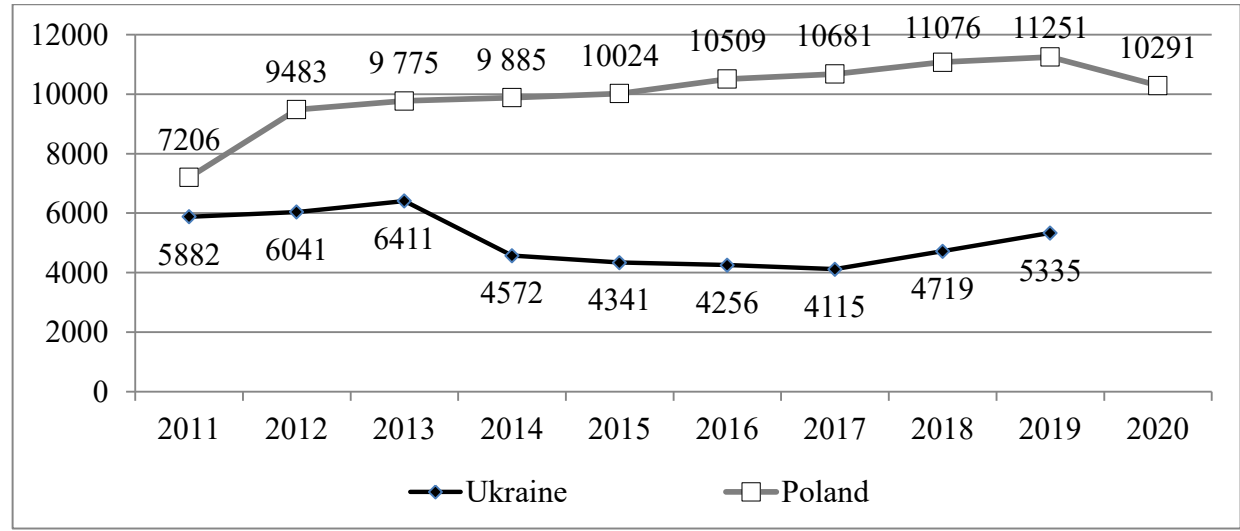

Figure 2. Dynamics of the number of temporary accommodation facilities in 2011-2020 in Ukraine and Poland

Source: Statistic Poland; The State Statistics Service of Ukraine 
Table 3

Travel restrictions related to the COVID-19 pandemic in Ukraine and Poland

\begin{tabular}{|c|c|c|}
\hline month & Ukraine & Poland \\
\hline April 2020 & total border closure & total border closure \\
\hline May 2020 & total border closure & total border closure \\
\hline June 2020 & total border closure & partial border closure \\
\hline July 2020 & other measures & partial border closure \\
\hline September 2020 & total border closure & partial border closure \\
\hline November 2020 & other measures & partial border closure \\
\hline February 2021 & testing / quarantine & total border closure \\
\hline
\end{tabular}

Source: World Tourism Organization, 2021

For international tourists the rate is even higher: $21.8 \%$, 94.2\%, 65.5\%, and $83.8 \%$, respectively (Statistic Poland, 2021).

Fear of COVID-19 and perceived risk significantly affect the attitudes of Ukrainian and Polish residents toward tourism, but the desire to travel remains unchanged. The need to catch up is very strong. Practice shows that the closure of borders encouraged people to travel within their countries (mostly in private cars). Tourists nowadays prefer green tourism to staying in large hotels, and instead of group tours they choose individual trips with safety precautions. Meanwhile, travel agencies in Ukraine and Poland began to pay more attention to the domestic market, looking for new places and destinations that were not popular before. Nevertheless, it is worth emphasizing that consumers of travel services are "tired" of a pandemic that pushes them to risk their health. An example is the winter ski season in Ukraine, when many people visited ski resorts under blocked conditions. This led to new outbreaks of COVID-19 in the regions.

\section{Conclusions}

Tourism plays an important role in the economy of Ukraine and Poland and is closely linked with other industries. Therefore, its crisis condition caused by the COVID-19 pandemic affects the economy in general. The recovery of the tourism industry is taking longer than expected. Changes in the behavior of tourist services' consumers show that the approach to marketing the tourism industry must be radically revised, both at the national and local levels. Namely, it is necessary to consider the following measures to improve the tourist branding of Ukraine:

- positioning: demonstrating the unique strengths of the tourist potential of countries, taking into account the new needs of consumers of tourist services. In particular, messages that are emotionally warm and full of happiness and security should be developed to meet consumers' needs for emotional warmth and a sense of security. It is also worth considering the needs of consumers in a sense of solidarity in a crisis, so the message should demonstrate a moment of unity and change the situation. Moreover, positioning that demonstrates the opportunity to take advantage of the best tourist offers at the moment (in this context, the current Ukrainian brand meets this requirement) will be useful to reduce consumers' sense of loss of time, opportunity, the experience of isolation. To emphasize the safety of travel, it should be pointed out that the travel offerings are based on the recommendations of the World Health Organization and the countries' Ministries of Healthcare;

- promotion: given the sharp transition of life in modern society from offline to online, we should make maximum use of modern technology, reducing the distance to consumers of tourist services, so to speak, at arm's length. It includes promotion of travel websites and channels/accounts on YouTube, Instagram, Facebook, maximum exposure on social media; creation of mobile electronic applications for smartphones and tablets. It is important to invest in the online presence and reputation of the countries' tourism brands (likes, shares, online reviews). In addition, classic cross-promotions and broadcasts of promotional video content in countries and abroad, etc. should be carried out. It is worthwhile to conduct positive outreach activities that address the interests and needs (described above) of the general public and debunk the myths and cautions tourists have about counties.

In addition to improving marketing, to develop strong brands of Ukraine and Poland in the context of the pandemic, attention should be paid to the following key components of tourism competitiveness:

Ukraine: Safety and Security, Natural Resources, ICT Readiness, Air Transport Infrastructure, Ground and Port Infrastructure, Tourist Service Infrastructure.

Poland: Safety and Security, Air Transport Infrastructure, Tourist Service Infrastructure.

Both countries: Business Environment, Prioritization of Travel \& Tourism, Environmental Sustainability.

Moreover, an alternative way to restore tourism is that Ukraine and Poland can not stand on opposite sides of the barricades in the fight for tourists, but 
join forces. In particular, this could be accomplished by creating a tourism alliance with each other, as in the Trans-Tasman Travel Bubble between New Zealand and Australia. Simplifying border crossing requirements and developing new and interesting tours on both sides increases tourist flows, helps to get to know the countries better and develop a vision for their tourism brands. However, the epidemiological level is the only precautionary measure here, because, unlike the countries mentioned, things are much worse in Ukraine and Poland. Nevertheless, it is possible to find other ways to cooperate.

In general, brand strategies in Ukraine and Poland should take into account the new paradigm of consumer behavior and be based on building their trust in safe and interesting tourism. The implementation of comprehensive and consistent measures in this direction at all levels will allow countries to compete worthily for investments, tourists and partners and to quickly reboot tourism.

\section{References:}

Anholt, S. (2010). Definitions of place branding - Working towards a resolution. Place Brand Public Dipl, 6, 1-10. DOI: https://doi.org/10.1057/pb.2010.3

Aronczyk, M. (2008). Living the Brand: Nationality, Globality and the Identity Strategies of Nation Branding Consultants. International Journal of Communication, 2, 43, 54.

Bauer, R. A. (1967). Consumer Behavior as Risk Taking. Risk Taking \& Information Handling in Consumer Behavior, Graduate School of Business Administration, Harvard University, Boston, 23-33.

Bloom Consulting (2021). Country Brand Ranking Tourism edition 2019/2020. Available at: https:/Twww.bloom-consulting.com/en/pdf/rankings/Bloom_Consulting_Country_Brand_Ranking_Tourism.pdf

Bondarenko, Yu., \& Romaniuk, E. (2021). State and prospects of tourism development during the pandemic. SEMI, 5(1), 132-143. DOI: https://doi.org/10.23939/semi2021.01.132

Decentralization (2021). Case study. Brand and marketing territories. What is the secret of the most successful cities in Ukraine. Available at: https://decentralization.gov.ua/uploads/library/file/486/Regional_Branding Marketing_2019.pdf

Future brand (2021). Future Brand Country Index 2019. Available at: https://www.futurebrand.com/uploads/ FCI/FutureBrand-Country-Index-2019.pdf

Google Play App (2021). Available at: https://play.google.com/store/search?q=poland\&c=apps\&hl=ru

Gössling, S., Scott, D., \& Hall, C. M. (2021). Pandemics, tourism and global change: a rapid assessment of COVID-19. Journal of Sustainable Tourism, 29:1, 1-20. DOI: https://doi.org/10.1080/09669582.2020.1758708

Kotler, P., Haider, D. \& Rein, I., (1993). Marketing Places: Attracting Investment, Industry and Tourism to Cities, States and Nations. New York: The Free Press.

Letunovska, N., \& Lyulyov, O. (2020). Marketing in tourism. Sumy: Sumy State University.

Matiza, T., (2020). Post-COVID-19 crisis travel behaviour: towards mitigating the effects of perceived risk. Journal of Tourism Futures, Vol. ahead-of-print No. ahead-of-print. DOI: https://doi.org/10.1108/JTF04-2020-0063

Nikolaichuk, O. (2020). Tourist branding policy for promoting national tourist products: central East European countries experience. Galician economik journal, 2(63). DOI: https://doi.org/10.33108/ galicianvisnyk tntu2020.02

Novelli, M., Milano, C., \& Cheer, J., (2018). Overtourism a growing global problem. The conversation. Available at: https://www.researchgate.net/publication/326573468_Overtourism_a_growing_global_problem

Prokopenko, O., \& Omelyanenko, V. (2020). Intellectualization of the Phased Assessment and Use of the Potential for Internationalizing the Activity of Clusters of Cultural and Creative Industries of the Baltic Sea Regions. TEM Journal, 9(3), 1068-1075. DOI: https://doi.org/10.18421/TEM93-31

State Agency for Tourism Development of Ukraine (2021). Available at: https://www.tourism.gov.ua/news-andannouncements

Statistic Poland (2021). Statistical yearbook of the republic of poland 2020 Available at: https://stat.gov.pl/en/ topics/statistical-yearbooks/statistical-yearbooks/statistical-yearbook-of-the-republic-of-poland-2020,2,22.html The Polish Tourism Organisation (2021). Available at: https://www.pot.gov.pl/pl/o-pot/informacje-o-pot The State Statistics Service of Ukraine (2021). Statistics. Available at: http:/ /www.ukrstat.gov.ua/ The United Nations (2020). It is imperative that we rebuild the tourism sector. Available at: https://www.un.org/ en/coronavirus/it-imperative-we-rebuild-tourism-sector

The World Bank (2020). Annual report 2020. Available at: https://www.worldbank.org/en/about/annual-report The World Travel \& Tourism Council (2021). Economic Impact Reports. Available at: https://wttc.org/Research/ Economic-Impact

Tkach, S. (2013). Evaluation of level of internal investment risk in region. Naukovyi Visnyk Natsionalnoho Hirnychoho Universytetu, 2, 115-121.

Van Ham, P. (2001). The Rise of the Brand State: The Postmodern Politics of Image and Reputation. Foreign Affairs, 37-52. 
Web.archive.org (2014). Ukraine tourist brandbook. Available at: https://web.archive.org/web/2014072617 4526/http://tourism.gov.ua/files/brbook/ukraine_tourist_brand_brandbook_ukr_6.pdf

Wen, J., Kozak, M., Yang, S., \& Liu, F. (2021). COVID-19: potential effects on Chinese citizens' lifestyle and travel. Tourism Review. Vol. ahead-of-print No. ahead-of-print. DOI: https://doi.org/10.1108/TR-03-2020-0110 World Economic Forum (2019). The Travel \& Tourism Competitiveness Report 2019 Travel and Tourism at a Tipping Point. Available at: http://www3.weforum.org/docs/WEF_TTCR_2019.pdf

World Tourism Organization (2021). Covid-19 and tourism 2020. Available at: https://www.unwto.org/covid-19and-tourism-2020

Zenker, S., \& Braun, E. (2017). Questioning a "one size fits all" city brand: Developing a branded house strategy for place brand management. Journal of Place Management and Development, 10(3), 270-287. DOI: https://doi.org/10.1108/JPMD-04-2016-0018 